\title{
Características mecánicas de hormigones con áridos reciclados procedentes de los rechazos en prefabricación
}

\section{Mechanical characteristics of concrete with recycled aggregates coming from prefabricated discarded units}

\author{
J. A. Pérez-Benedicto ${ }^{(*)}$, M. del Río-Merino(**), J. L. Peralta-Canudo(*), \\ M. de la Rosa-La Mata(***)
}

Recepción/Received: 15-IX-10

Aceptación/Accepted: 04-XI-10

Publicado online/Online publishing: 4-XI-11

\section{RESUMEN}

La necesidad de disminuir la cantidad final de residuos de construcción y demolición que se producen en las plantas de prefabricados de hormigón nos ha llevado a analizar el comportamiento mecánico de un hormigón elaborado con áridos reciclados procedentes de piezas prefabricadas de hormigón, con la finalidad de un posible futuro uso como árido en dosificaciones de hormigón armado y pretensado para piezas prefabricadas. Se ha trabajado con áridos reciclados en dos situaciones: estado natural y sometidos a presaturación, con hormigones $\mathrm{H} 40$ y $\mathrm{H} 50$ autocompactantes, tomando como única variable la sustitución de fracción gruesa del árido $4 / 12 \mathrm{~mm}$ con los siguientes porcentajes, $0 \%, 20 \%, 50 \%$ y $100 \%$. Los resultados de los ensayos realizados indican que hormigones elaborados con áridos reciclados procedentes de elementos prefabricados pueden presentar una excelente calidad como hormigón estructural para su futuro uso como autoconsumo.

Palabras clave: árido reciclado, hormigón, dosificación, resistencia mecánica, residuos.

\section{SUMMARY}

The need to diminish the final amount of waste produced in construction and demolition processes in plants of concrete prefabricated products, has made us analyze the mechanical behaviour of concrete made with recycled aggregate coming from discarded concrete prefabricated units. The aim was to find a possible use for this recycled aggregate in different proportions in reinforced concrete and prestressed concrete, for prefabricated elements. Two situations using recycled aggregate have been studied: one of them, in natural state and subject to pre-saturation with selfcompacting $\mathrm{H} 4 \mathrm{O}$ and $\mathrm{H} 5 \mathrm{O}$ concrete, using as the only variable the substitution of the 4/12 $\mathrm{mm}$ coarse aggregate in the following percentages: $0 \%, 20 \%, 50 \%$ and $100 \%$. The results of the tests performed indicate that concretes with recycled aggregate coming from discarded prefabricated units can offer an excellent quality as structural concrete for future uses.

Keywords: recycled agrégate, concrete, proportion, mechanical strength, waste.

(*) Universidad de Zaragoza (La Almunia, España).

(**) Universidad Politécnica de Madrid (Madrid, España).

(***) Laboratorio Arco Tecnos (Zaragoza, España). 


\section{INTRODUCCIÓN}

El creciente aumento en la generación de residuos y la falta de lugares donde depositarlos impone a la sociedad la necesidad de habilitar mecanismos de gestión que permitan dar una respuesta adecuada ante tal situación. El sector de la construcción debe dar respuesta y aportar soluciones sostenibles que minimicen los efectos de los residuos que generan, promoviendo iniciativas de reciclado dentro de la propia actividad.

Este estudio analiza la viabilidad de la utilización del árido reciclado (AR) procedente de las piezas prefabricadas de desecho que se generan durante el proceso de fabricación en la planta de prefabricados de la empresa PRAINSA en Zuera (Zaragoza), como árido en dosificaciones de hormigón armado y pretensado de autoconsumo.

La fábrica de PRAINSA desecha un $5 \%$ del total de las piezas fabricadas en los procesos de calidad. Estos elementos, durante todo su proceso, sufren un exhaustivo control que garantiza una mayor homogeneidad del AR con respecto a los fabricados con productos de demoliciones de hormigón, asegurando la no contaminación del mismo con agentes exteriores.

Las características del AR que se puede obtener y la homogeneidad de sus propiedades están estrechamente ligadas con las correspondientes características del hormigón original, por lo que conocer la historia del mismo es de gran relevancia para evaluar el hormigón final.

El trabajo de investigación realizado se ha centrado en la parametrización de los AR procedentes del autoconsumo y su relación con el árido natural de origen, así como en el estudio mediante moldeo de probetas de hormigón reciclado, de sus propiedades mecánicas, ensayando la resistencia mecánica a compresión, resistencia a tracción, grado de absorción y densidad.

\section{MATERIALES Y MÉTODOS}

\subsection{Materiales}

El AR empleado en el estudio proviene de la no calidad en prefabricación, caracterizándose por proceder de piezas prefabricadas hormigonadas con hormigones que garantizan resistencias mínimas de $\mathrm{H} 30$ a H50, sin estar sometidos a ningún proceso externo de contaminación.

La Tabla 1 muestra la distribución de los distintos hormigones que componen las piezas que han servido de materia prima para la elaboración del $A R$, en porcentajes del volumen de material de desecho (Figura 1).

\section{INTRODUCTION}

The increasing generation of waste and the lack of dumps for its disposal, forces society to find mechanisms for its management and to provide an adequate response to the situation. The construction sector has to provide sustainable solutions in order to minimize the effects of the waste generated, promoting recycling initiatives within the construction activity.

This research work analyzes the feasibility of use of recycled aggregate ( $R A$ ) coming from rejected prefabricated pieces, which have been produced during the manufacturing process at PRAINSA, a prefabricated concrete plant in Zuera (Zaragoza). This aggregate is incorporated in different proportions in reinforced concrete and pre-stressed concrete for the plant's consumption.

PRAINSA plant rejects $5 \%$ of the total quantity of manufactured pieces in the quality process they undergo. These elements, during all their process, suffer a comprehensive control ensuring a greater homogeneity of the $R A$ regarding the products manufactured with concrete demolition waste and ensuring the lack of contamination with external agents.

Characteristics of the $R A$ obtained and the homogeneity of its properties are closely linked to the corresponding characteristics of the original concrete. Therefore, it is of great importance to know the original base concrete in order to asses the final concrete obtained.

The research work carried out has focussed on the parameter standardization of the RA coming from selfconsumption and their relation with the natural aggregate of origin. At the same time, this research studies sample specimens of recycled concrete and their mechanical properties, being tested to mechanical compressive strength, tensile strength, absorption degree and density.

\section{MATERIALS AND METHODS}

\subsection{Materials}

$R A$ used in this study comes from the discarded pieces in prefabrication processes, and these pieces are characterized by being manufactured with concretes ensuring an $\mathrm{H} 30$ to $\mathrm{H} 50$ resistance, without being subject to any external contamination process.

Table 1 shows the distribution of the different concretes used for the pieces, which have formed the raw material for the production of $R A$, in percentages of volume of discarded material (Figure 1) 
Tabla 1 / Table 1

Porcentaje de los distintos hormigones que conforman las piezas de desecho.

Percentage of the different concretes forming the discarded pieces.

\begin{tabular}{|c|c|}
\hline \% del desecho total / \% of total waste & Piezas / Units \\
\hline 82.53 & HPAC-40: Placas alveolares / Cell plank \\
\hline 2.39 & HAC-40: Correa tubular, dalla y pilares armados / Tubular strap, dalla and reinforced pillars \\
\hline 8.63 & HAC-30: Paneles armados / Reinforced panels \\
\hline 6.55 & HPAC-50: Vigas pretensadas / Prestressed beams \\
\hline
\end{tabular}

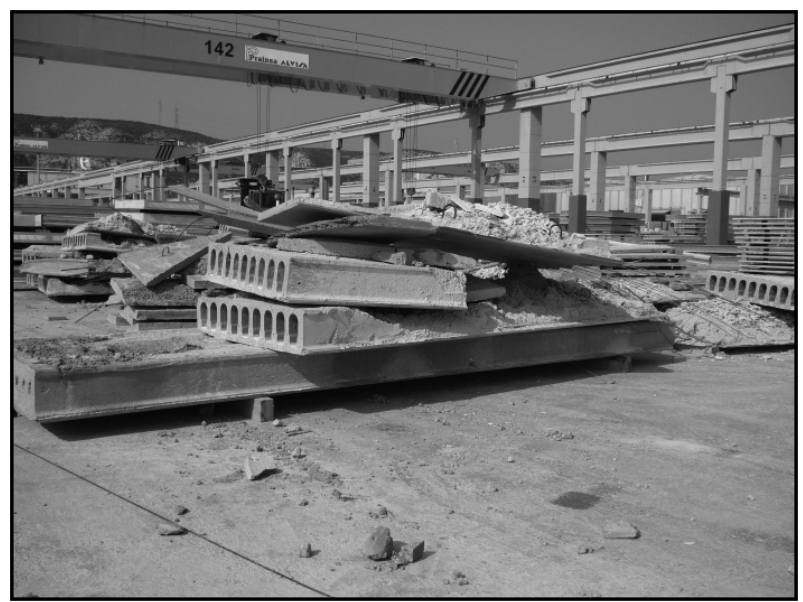

Figura 1. Fotografía de elementos prefabricados desechados. Figure 1. Picture of the discarded prefabricated units.

Para todas las dosificaciones se han usado hormigones autocompactantes con la incorporación de un aditivo plastificante, soluble al agua, con un $\mathrm{pH}$ mín. de 9 y exento de cloruros o bien de un superplastificante a base de policarboxilatos modificados con un $\mathrm{pH}$ de 8 e igualmente exento de cloruros, con las dosificaciones que se recogen en la Tabla 2.

El cemento utilizado fue el mismo que el usado en el proceso de prefabricación, CEM I 52,5 R, fabricado por CEMEX España S.A. y elaborado en $\mathrm{Cl}$ Afuera, $s / n$ de Morata de Jalón (Zaragoza).
For every sample batch self-compacting concrete has been used, adding either a plasticizer additive, water soluble, with a minimum $\mathrm{pH}$ of 9 and with no chloride, or a superplasticizer of polycarboxilae base, with a $\mathrm{pH}$ of 8 and also with no chloride, in the proportions shown in Table 2.

The cement used has been the same as the one used for the production of the prefabricated units, i.e. CEM I 52,5 R, supplied by CEMEX Spain and produced at Cl Afuera, $s / n$ de Morata de Jalón (Zaragoza).

Tabla 2 / Table 2

Dosificación de los distintos hormigones utilizados en la fabricación de las piezas de desecho. Proportion of different concretes used in the production of discarded concrete units.

\begin{tabular}{|c|c|c|c|c|c|}
\hline Componente / Component & $\begin{array}{c}\text { Cloruros solubles / } \\
\text { soluble chlorides } \\
\text { Máx. (\%) }\end{array}$ & $\begin{array}{c}\text { HPAC-40 } \\
\left(\mathrm{kg} / \mathrm{m}^{3}\right)\end{array}$ & $\begin{array}{l}\text { HAC-30 } \\
\left(\mathrm{kg} / \mathrm{m}^{3}\right)\end{array}$ & $\begin{array}{l}\text { HAC-40 } \\
\left(\mathrm{kg} / \mathrm{m}^{3}\right)\end{array}$ & $\begin{array}{c}\text { HPAC-50 } \\
\left(\mathrm{kg} / \mathrm{m}^{3}\right)\end{array}$ \\
\hline AFT-0 / 4 S-L & 0.01 & 1157 & 960 & 960 & 813 \\
\hline AGT-6 / 12 S-L & 0.01 & 590 & 365 & 393 & 840 \\
\hline AGR-6 / 12 S-L & 0.01 & 0 & 360 & 403 & 0 \\
\hline Filler calizo / Sandsotne Filler & 0.002 & 0 & 190 & 125 & 165 \\
\hline Cemento / Cement I 52.5 R & 0.01 & 400 & 330 & 360 & 400 \\
\hline Plastificante / Plasticizer & 0 & 0.5 & 0 & 0 & 0 \\
\hline Superfluidificante / Superfluidifier & 0 & 0 & 5.5 & 6 & 6.35 \\
\hline Agua / Water & 0.005 & 200 & 165 & 180 & 200 \\
\hline \multicolumn{2}{|c|}{ Densidad 28 días / Density 28 days $\left(\mathrm{Kg} / \mathrm{m}^{3}\right)$} & 2283 & 2326 & 2368 & 2365 \\
\hline \multicolumn{2}{|c|}{ Cloruros solubles totales / Total soluble chlorides \% } & 0.01 & 0.0087 & 0.0089 & 0.0094 \\
\hline \multicolumn{2}{|c|}{ Rc 28d (MPa) } & 42 & 32 & 42 & 53 \\
\hline \multicolumn{2}{|c|}{ Aire ocluido / Entrained air \% } & $<6$ & $<2$ & $<2$ & $<2$ \\
\hline
\end{tabular}


Los áridos naturales empleados para la fabricación de la totalidad de los elementos prefabricados, así como para la fabricación de los hormigones en estudio, presentan como componentes principales: calcita, cuarzo, fragmentos de roca (caliza, cuarcita, metarenisca, cherts, pizarra y granito), cumpliendo con las exigencias de la actual Instrucción para Hormigón Estructural EHE 08.

El tratamiento seguido para la fabricación del AR ha consistido en la trituración previa de todas las piezas mediante pinza o martillo percutor, dejándolo el material a un tamaño máximo de $300 \mathrm{~mm}$. En esta fase se separó la ferralla de mayor tamaño, cables e hilos de pretensado y armaduras pasivas. Posteriormente los bloques se trituraron con una cuchara hasta reducirlos a un tamaño de 0 a $50 \mathrm{~mm}$, eliminando la ferralla de menor tamaño en una cinta separadora.

Con el árido exento de ferralla se realizó un nuevo proceso de trituración mediante molino y cribado con cinta, al objeto de seleccionar mediante tamizado únicamente la fracción 4/12. Como fase final y previo a su uso posterior para la fabricación de los hormigones estudiados se realizó un proceso de lavado.

La Tabla 3 recoge la dosificación de los distintos componentes para cada una de las tipologías de hormigón estudiadas.

\subsection{Programa experimental}

El estudio experimental desarrollado ha evaluado las propiedades del AR que se genera con áridos procedentes de la no calidad en prefabricación, frente al árido natural de procedencia, de acuerdo a las exigencias de la Instrucción de Hormigón Estructural EHE-08. Los resultados de
Natural aggregates used in the manufacture of all the prefabricated elements, as well as for the concrete to be studied, have as main components: calcite, quartz, stone fragments (sandstone, quartzite, metasandstone, cherts, slate and granite), fulfilling the requirements of the in force regulation for Structural Concrete, EHE 08.

The treatment followed for the production of $R A$ has been grinding previously all the pieces by using percussion hammer, leaving the material to a size of $300 \mathrm{~mm}$ maximum. At this stage, the steelwork of greater size was separated, such as prestressing cables and strands and passive reinforcements. Later, the blocks were grinded with a bucket until they were reduced to a 0 to $50 \mathrm{~mm}$ size, eliminating the smallest sized steelwork by a conveyor belt.

Once the aggregate has been separated from the steelwork, a new grinding process took place by means of a mill, sorting it out it with a separating belt, so that the 4/12 fraction could later be selected with a sieve. At this final stage and before it was used for the production of the studied concretes, the material went through a washing process.

Table 3 includes the different proportions of the components used for each of the concrete typologies studied.

\subsection{Experimental program}

The experimental survey carried out has assessed the properties of $R A$ generated with aggregates from discarded quality prefabrication products, as opposed to natural aggregate, complying with the Structural Concrete regulations EHE-08. The results of the tests

Tabla 3 / Table 3

Dosificación de los distintos hormigones estudiados. Proportions of the different concretes studied.

\begin{tabular}{|c|c|c|c|c|c|c|c|}
\hline \multicolumn{8}{|c|}{ Pruebas de laboratorio. Mezclas de 30 litros (mezclas $1 \mathrm{~m}^{3}$ ) / Lab tests. Mixes $30 \mathrm{~L}$ (mixes $1 \mathrm{~m}^{3}$ ) } \\
\hline $\begin{array}{c}\text { Mezcla en seco / } \\
\text { Mix dry }\end{array}$ & $\begin{array}{c}\text { Arena / } \\
\text { Sand (kg) }\end{array}$ & $\begin{array}{c}\text { Grava / } \\
\text { Gravel (kg) }\end{array}$ & $\begin{array}{c}\text { Grava reciclada } \\
\text { lavada / Washed } \\
\text { recycled gravel }(\mathrm{kg})\end{array}$ & $\begin{array}{l}\text { Becontres } \\
(\mathbf{k g})\end{array}$ & $\begin{array}{c}\text { Cemex } \\
\text { (kg) }\end{array}$ & P-345 (g) & $\begin{array}{c}\text { Relación a/c / } \\
\text { w/c ratio }\end{array}$ \\
\hline \multicolumn{8}{|c|}{ Hormigón pretensado / Prestressed concrete } \\
\hline HAC 50-0 & $24(800)$ & $25.2(840)$ & - & $4.95(165)$ & $12(400)$ & $204(680)$ & 0.43 \\
\hline HAC 50-20 & $24(800)$ & $20.2(673.3)$ & $5.04(168)$ & $4.95(165)$ & $12(400)$ & $204(680)$ & 0.43 \\
\hline HAC 50-50 & $24(800)$ & $12.6(420)$ & $12.6(420)$ & $4.95(165)$ & $12(400)$ & $204(680)$ & 0.43 \\
\hline $\begin{array}{l}\text { HAC 50-100 } \\
\text { HAC 50-100S }\end{array}$ & $24(800)$ & - & $25.2(840)$ & $4.95(165)$ & $12(400)$ & $204(680)$ & 0.43 \\
\hline \multicolumn{8}{|c|}{ Hormigón armado / Reinforced concrete } \\
\hline HAC 40-0 & $24(800)$ & $25.2(840)$ & - & $6.15(205)$ & $10.8(360)$ & $184(613.33)$ & 0.44 \\
\hline HAC $40-20$ & $24(800)$ & $20.2(673.3)$ & $5.04(168)$ & $6.15(205)$ & $10.8(360)$ & $184(613.33)$ & 0.44 \\
\hline HAC $40-50$ & $24(800)$ & $12.6(420)$ & $12.6(420)$ & $6.15(205)$ & $10.8(360)$ & $184(613.33)$ & 0.44 \\
\hline $\begin{array}{l}\text { /HAC 40-100 } \\
\text { HAC 40-100S }\end{array}$ & $24(800)$ & - & $25.2(840)$ & $6.15(205)$ & $10.8(360)$ & $184(613.33)$ & 0.44 \\
\hline
\end{tabular}


los ensayos corresponden a una fase inicial de la investigación, que se completaran con futuros trabajos.

Las dosificaciones para elaborar las mezclas de los hormigones se realizaron de acuerdo con los mismos parámetros que se estaban usando para la fabricación de las piezas sin AR, incorporando como única variable la sustitución de la fracción de árido grueso 4-12 mm. en porcentajes de: $0 \%$, $20 \%$, $50 \%$ y $100 \%$, para dosificaciones de hormigón armado y pretensado, con áridos sin presaturar y sustituciones del $100 \%$ con árido sometido a presaturación, manteniendo el árido sumergido en agua durante 24 horas y posteriormente a las 24 horas, secando la superficie mediante paño, al objeto de asegurar la máxima densidad saturada superficie seca.

El cálculo de la humedad permitió compensar la dosificación de arena y agua en función de la humedad medida en el microondas, quedando la relación $\mathrm{a} / \mathrm{c}$ con valores de 0,43 para HAC-50 y 0,44 para HAC-40.

La toma de muestras de hormigón fresco, con el que se elaboraron probetas normalizadas, se realizó según la Norma UNE-EN 12350-1 y el curado de las probetas se realizó en cámara húmeda, según la Norma UNE 83-301-91, hasta fecha de rotura: 7 y 28 días.

Control de la consistencia: los valores de consistencia se fijaron mediante el ensayo de escurrimiento, con la medición de la torta de hormigón, según la Norma UNE 83361, analizando cuatro amasadas distintas para cada una de las siguientes dosificaciones de HAC-50 con porcentajes de sustitución de AR sin someterlo a presaturación de $0 \%$, $20 \%, 50 \%$ y $100 \%$ y del $100 \%$ de AR presaturado.

Densidad: se analizaron un total de 12 probetas cúbicas de $10 \times 10 \times 10 \mathrm{~cm}$, de 6 dosificaciones distintas, de acuerdo a la norma UNE-EN 12390-7:09, amasadas con áridos sin someterlos a saturación previa y con sustituciones para HAC-40 de $0 \%, 50 \%$ y $100 \%$ y HAC-50 de $0 \%$, $50 \%$ y $100 \%$.

Absorción: se analizaron un total de 12 probetas cúbicas de $10 \times 10 \times 10 \mathrm{~cm}$. de 6 dosificaciones distintas, amasadas con áridos sin someterlos a saturación previa y con sustituciones para HAC- 40 de $0 \%, 50 \%$ y $100 \%$ y HAC-50 de $0 \%, 50 \%$ y $100 \%$, de acuerdo a la norma UNE-EN 1916 y UNE-EN 1339.

Resistencia a tracción: se fabricaron dos amasadas de 3 probetas cilíndricas de $30 \times 15 \mathrm{~cm}$, según la norma UNE-EN 12390-6:2001.

Resistencia a compresión: dos amasadas de 7 probetas cúbicas de $10 \mathrm{~cm}$ de lado para evaluar de igual manera la resistencia a compresión según la norma UNE-EN 12390-3. correspond to an initial stage of the research, which will be followed and completed with future works.

Proportions to carry out the concrete batches were performed in agreement with the same parameters being used in the manufacture of pieces without $R A$, incorporating as the only variable the substitution of the 4-12 $\mathrm{mm}$ fraction of coarse aggregate, in percentages of $0 \%, 20 \%, 50 \%$ and $100 \%$ for proportions of reinforced concrete and prestressed concrete, without presaturated aggregates. Substitutions of $100 \%$ were performed, with aggregate subject to presaturation maintaining the aggregate water immersed for a period of 24 hours, and later drying the surface, so as to ensure the maximum dry surface saturated density.

Humidity calculation provided the possibility to compensate the sand and water proportion in relation to the moisture measured in the microwave, obtaining a $\mathrm{W} / \mathrm{c}$ ratio with values of $=0.43$ for HAC-50 and 0.44 for HAC-40.

Samples of fresh concrete to carry out the standard specimens were done following the UNE-EN 12350-1 standard, and the specimen curing was done in a moisture chamber, regarding the UNE 83-301.91 standard, until fracture time: 7 and 28 days.

Consistency control: concrete consistency values were fixed by the slump test, following UNE 83361 standard, and analyzing four different batches for each one of the following proportions of HAC-50, with RA substitution percentages without being subject to pre-saturation of $0 \%, 20 \%, 50 \%$ and $100 \%$, and of $100 \%$ of presaturated $R A$.

Density: a total of 12 cubic specimens of $10 \times 10 \times 10 \mathrm{~cm}$, and 6 different proportions have been studied, following UNE-EN 1239-7:09 standard. The batches have been mixed with aggregates without being subject to previous saturation and substitutions of $0 \%, 50 \%$ and $100 \%$ for HAC- -40 , and of $0 \%, 50 \%$ and $100 \%$ for HAC- 50 .

Absorption: a total of 12 cubic specimens of $10 \times 10 \times 10 \mathrm{~cm}$, in 6 different proportions have been studied, mixed with aggregates without being subject to prior saturation and with substitutions of $0 \%, 50 \%$ and $100 \%$ for HAC-40, and $0 \%, 50 \%$ and $100 \%$ for HAC-50, following the UNE-EN 1916 and the UNE-EN 1339 standards.

Tensile strength: two batches were performed in 3 cylindrical specimens of $30 \times 15 \mathrm{~cm}$, following UNE-EN 12390-6:2001 standard.

Compression strength: two batches were performed in 7 cubic specimens of side $10 \mathrm{~cm}$ to assess the compressive strength in agreement with the UNE-EN 12390-3 standard. 


\section{RESULTADOS Y DISCUSIÓN}

\subsection{Propiedades de los áridos}

La Tabla 4 compara las características del árido natural de referencia, utilizado en el proceso de prefabricación y en los hormigones de control, con el AR de este estudio y el empleado por otros autores (1,3-10). Los ensayos realizados en la parametrización del AR han presentado un excelente comportamiento, quedando únicamente la absorción y la resistencia a la helada con sustituciones del $100 \%$ con valores algo superiores a los máximos exigidos por la Instrucción de Hormigón Estructural EHE-08 para árido natural.

\section{RESULTS AND DISCUSSION}

\subsection{Properties of the aggregates}

Table 4 compares the characteristics of the natural reference aggregate, with the $R A$ of this study, and the one used by other authors (1,3-10). Tests performed for the parameters of the RA have shown an excellent performance. However, only the absorption and the frost strength in $100 \%$ substitutions have kept values higher than the maximum required in the EHE-08 Structural Concrete Regulations for natural aggregate.

Tabla 4 / Table 4

Comparativa de características de los áridos reciclados y los naturales de origen. Comparison of the characteristics of the recycled aggregates and the original natural ones.

\begin{tabular}{|c|c|c|c|c|}
\hline \multicolumn{5}{|c|}{$\begin{array}{l}\text { Comparativa de ensayos de los áridos reciclados (fracción 4/12) y los naturales de origen / Comparison of recycled aggregate tests } \\
\text { (fraction 4/12) and original natural aggregates }\end{array}$} \\
\hline \multirow[b]{2}{*}{ Ensayo / Test } & \multicolumn{4}{|c|}{ Resultados de los ensayos / Test results } \\
\hline & $\begin{array}{l}\text { Limitaciones / } \\
\text { Limitations EHE-08 }\end{array}$ & $\begin{array}{l}\text { Áridos reciclados / } \\
\text { Recycled aggregates } \\
\text { (fracción 4/12) }\end{array}$ & $\begin{array}{l}\text { Áridos de origen } \\
\text { triturados / Grinded } \\
\text { aggregates } \\
\text { (fracción 6/12) }\end{array}$ & $\begin{array}{l}\text { Valores de referencia } \\
\text { bibliografía consultada / } \\
\text { Reference values from } \\
\text { bibliography studied }\end{array}$ \\
\hline Índice de lajas / Slab index & UNE-EN 933-3/A1:2004 & $4(\leq 35)$ & $11(\leq 35)$ & $7-20.90(1-3)$ \\
\hline $\begin{array}{l}\text { Coeficiente de forma / } \\
\text { Hape coefficient }\end{array}$ & UNE-EN 933-4:2000 & 4 & 11 & $0.20-0.235 \%(1,3)$ \\
\hline $\begin{array}{l}\text { Densidad de partículas } \\
\text { saturadas S.S. }\left(\mathrm{Mg} / \mathrm{m}^{3}\right) /: \\
\text { Saturated particle density } \\
\text { S.S. }\left(\mathrm{Mg} / \mathrm{m}^{3}\right)\end{array}$ & - & 2.43 & 2.57 & 2.30 a $2.53(4-7)$ \\
\hline Absorción / Absorption & $\leq 5 \%$ & $7.3 \%$ & $0.97 \%$ & 3.5 a $8.49 \%(1,2)(4,6-8)$ \\
\hline LA & $<40$ & 31 & 20 & $25-42 \%(1,2,4,9)$ \\
\hline $\begin{array}{l}\text { Material cerámico / } \\
\text { Ceramic material }\end{array}$ & $5 \%$ peso total / total weigth & $0 \%$ & $0 \%$ & - \\
\hline $\begin{array}{l}\text { Partículas ligeras / } \\
\text { Light particles }\end{array}$ & $1 \%$ peso total / total weigth & $0.3 \%$ & $0.1 \%$ & - \\
\hline Asfalto / Asphalt & $1 \%$ peso total / total weigth & $0 \%$ & $0 \%$ & - \\
\hline $\begin{array}{l}\text { Otros materiales (vidrio, } \\
\text { plásticos, etc.) / } \\
\text { Other materials (glass, } \\
\text { plastics, etc.) }\end{array}$ & $1 \%$ peso total / total weigth & $0 \%$ & $0 \%$ & - \\
\hline $\begin{array}{l}\text { Terrones de arcilla / } \\
\text { Clay lumps }\end{array}$ & $\begin{array}{c}<0,60 \% \text { AR- } 20 \%<0,25 \% \text { AR- } \\
100 \%<0,15 \% \text { AN }\end{array}$ & $0 \%$ & $0 \%$ & $0 \%(3)$ \\
\hline $\begin{array}{c}\text { Materia orgánica / } \\
\text { Organic material }\end{array}$ & & $0.01 \%$ & $0.01 \%$ & $0 \%(3)$ \\
\hline $\begin{array}{l}\text { Contenido de cloruros / } \\
\text { Chloride content }\end{array}$ & $<0,05 \% \mathrm{HA}<0,03 \% \mathrm{HP}$ & 0.01 & $0.00 \%$ & $0.04 \%(3)$ \\
\hline $\begin{array}{l}\text { Resistencia a la helada / } \\
\text { Frost strength }\end{array}$ & $\begin{array}{l}\text { Valor medio de sulfato de } \\
\text { magnesio MS } 18 \% \text { / Mean value } \\
\text { of manganese sulphate MS } 18 \%\end{array}$ & 20 & 1.8 & $2-22 \%(5,10)$ \\
\hline $\begin{array}{l}\text { Compuestos de azufre / } \\
\text { Sulphur compounds }\end{array}$ & $\mathrm{SO}_{3}<1 \%$ & $\mathrm{SO}_{3}=0.63 \%$ & $0.52 \%$ & $\begin{array}{c}0.43-0.75 \% \text { fracción/fraction } \\
(4 / 8 \mathrm{~mm}) / 0.34-0.52 \% \\
\text { fracción/fraction }(8 / 16 \mathrm{~mm})\end{array}$ \\
\hline $\begin{array}{l}\text { Contenido de sulfatos / } \\
\text { Solphate content }\end{array}$ & $\mathrm{SO}_{3}<0.8 \%$ & $0.49 \%$ & $0.4 \%$ & $\begin{array}{c}0.10-0.55 \% \text { fracción/fraction } \\
(4 / 8 \mathrm{~mm}) / 0.10-0.40 \% \text { fracción/ } \\
\text { fraction }(8 / 16 \mathrm{~mm})\end{array}$ \\
\hline
\end{tabular}




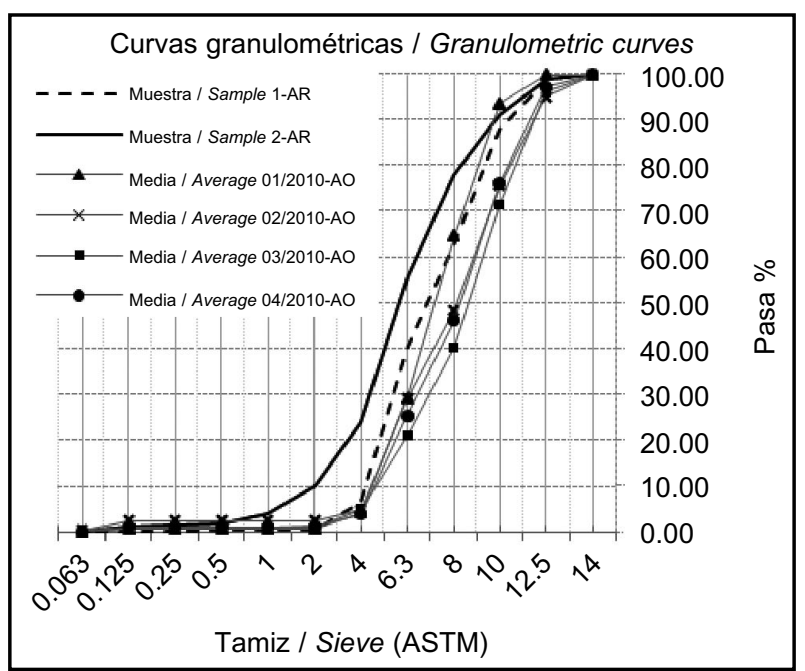

Figura 2. Curvas granulométricas de los áridos naturales y reciclados utilizados.

Figure 2. Granulometric curves of natural and recycled aggregates used.

En la Figura 2 se muestra una comparativa de las curvas granulométricas correspondientes a los ensayos de dos muestras de $A R$, frente a cuatro curvas correspondientes a la media mensual de los ensayos realizados semanalmente durante el proceso de control de calidad en la fábrica de prefabricados del árido natural. El análisis granulométrico se realizó sometiendo las muestras a un lavado previo y posterior secado natural.

Los gráficos muestran una pendiente granulométrica muy similar, con un desplazamiento en las curvas de AR procedente de piezas prefabricadas hacia las partículas finas del $10 \%$ al $20 \%$, como consecuencia de fracción de $4 \mathrm{~mm}$. del $A R$, no dispuesta en el árido triturado de origen.

\subsection{Control de la consistencia}

La Figura 3 muestra los valores de consistencia de cuatro amasadas distintas para cada una de las siguientes
Figure 2 shows a comparison of the granulometric curves corresponding to the mean monthly tests performed weekly during the process of quality control in the natural aggregate prefabricated plant. The granulometric analysis was performed washing the samples first, and later leaving them dry naturally.

Graphs show a very similar granulometric slope, with a displacement in the $R A$ curves coming from prefabricated units towards the finer particles of $10 \%$ and $20 \%$, as a consequence of the $4 \mathrm{~mm}$ fraction of $R A$ not included in the aggregate originally grinded.

\subsection{Consistency control}

Figure 3 shows the consistency values of 4 different batches for each of the following proportions of HAC-50

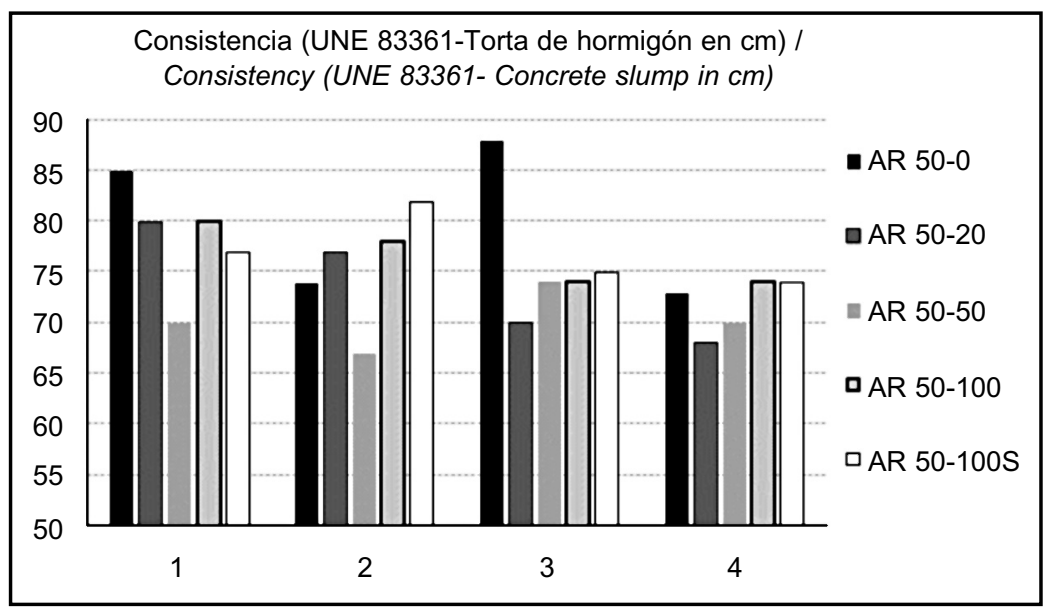

Figura 3. Comparativa de valores de consistencia sustituciones de $0 \%, 20 \%, 50 \%$ y $100 \%$ con AR sin presaturación y de $100 \%$ con AR presaturado.

Figure 3. Comparison of consistency values for $0 \%, 20 \%, 50 \%$ and $100 \%$ RA substitutions without pre-saturation, and of $100 \%$ with pre-saturated $R A$. 
dosificaciones de HAC-50 con porcentajes de sustitución de AR sin someterlo a presaturación de $0 \%, 20 \%, 50 \%$ y $100 \%$ y del $100 \%$ de AR presaturado.

Los resultados obtenidos no muestran relación directa entre la consistencia del hormigón y la condición de presaturación de los áridos, ni tampoco con la relación de AR en la mezcla.

A la vista de los resultados puede concluirse que, para hormigones autocompactantes, la acción de los superplastificantes incide de forma más directa en la fluidez que el resto de componentes del hormigón, para los casos estudiados.

\subsection{Densidad}

El rango de valores obtenidos en la situación de densidad seca en estufa, oscila entre $2,31-2,35 \mathrm{~kg} / \mathrm{dm}^{3}$ para el hormigón de control y 2,2-2,3 kg/dm³ para el hormigón reciclado.

La densidad de los hormigones reciclados está relacionada con los hormigones de control, siendo inferior a la del hormigón de control. Los descensos de densidad máximos obtenidos son inferiores al 5\% para los hormigones con sustituciones del $100 \%$ respecto a los de control.

En la Figura 4 se puede apreciar la evolución de la densidad en función del \% de AR sustituido y su relación con la bibliografía consultada $(4,5,11)$.

\subsection{Absorción}

El rango de valores obtenidos oscila del 2,85\% para el hormigón de control H40, a 4,77\% para el hormigón H50 con sustitución del $100 \%$ de AR. with RA substitution percentages of $0 \%, 20 \%, 50 \%$ and $100 \%$ without being subject to pre-saturation, and of $100 \%$ of pre-saturated $R A$.

Results obtained do not show a direct correlation between concrete consistency and the aggregate presaturation condition, and neither does exist with the proportion of RA in the batch.

As can be observed from the results, it can be concluded that, for selfcompacting concretes, the action of the superplasticizers affects more directly upon the flow than the other concrete components, in the cases studied.

\subsection{Density}

The range of values obtained in the situation of the heater dry density, oscillates between $2.31-2.35 \mathrm{~kg} / \mathrm{dm}^{3}$ for the reference concrete, and $2.2-2.3 \mathrm{~kg} / \mathrm{dm}^{3}$ for recycled concrete.

The density of the recycled concrete is related to that of the reference concrete, being lower than that one. The maximum density decreases obtained are smaller than $5 \%$ for concretes with substitutions of $100 \%$ in relation to the reference one.

Figure 4 shows the evolution of density in relation to the percentage (\%) of RA substituted and its relation to the bibliography studied $(4,5,11)$.

\subsection{Absorption}

The scope of values obtained ranges from $2.85 \%$ for the H40reference concrete, to $4.77 \%$ for $\mathrm{H} 50$ with a $100 \%$ substitution of $R A$.

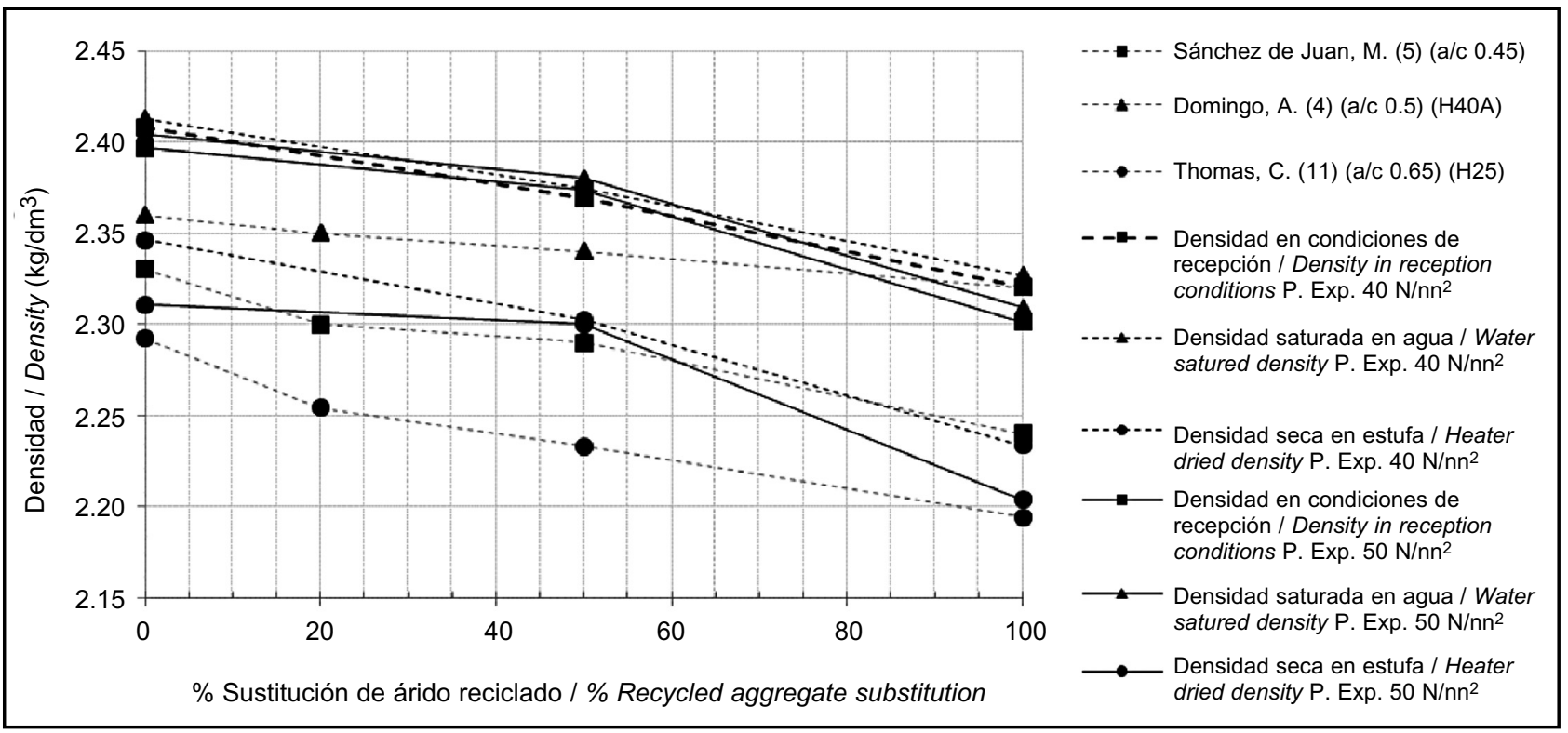

Figura 4. Relación entre la densidad y el porcentaje de sustitución de árido reciclado.

Figure 4. Relation between density and substitution percentage of recycled aggregate. 


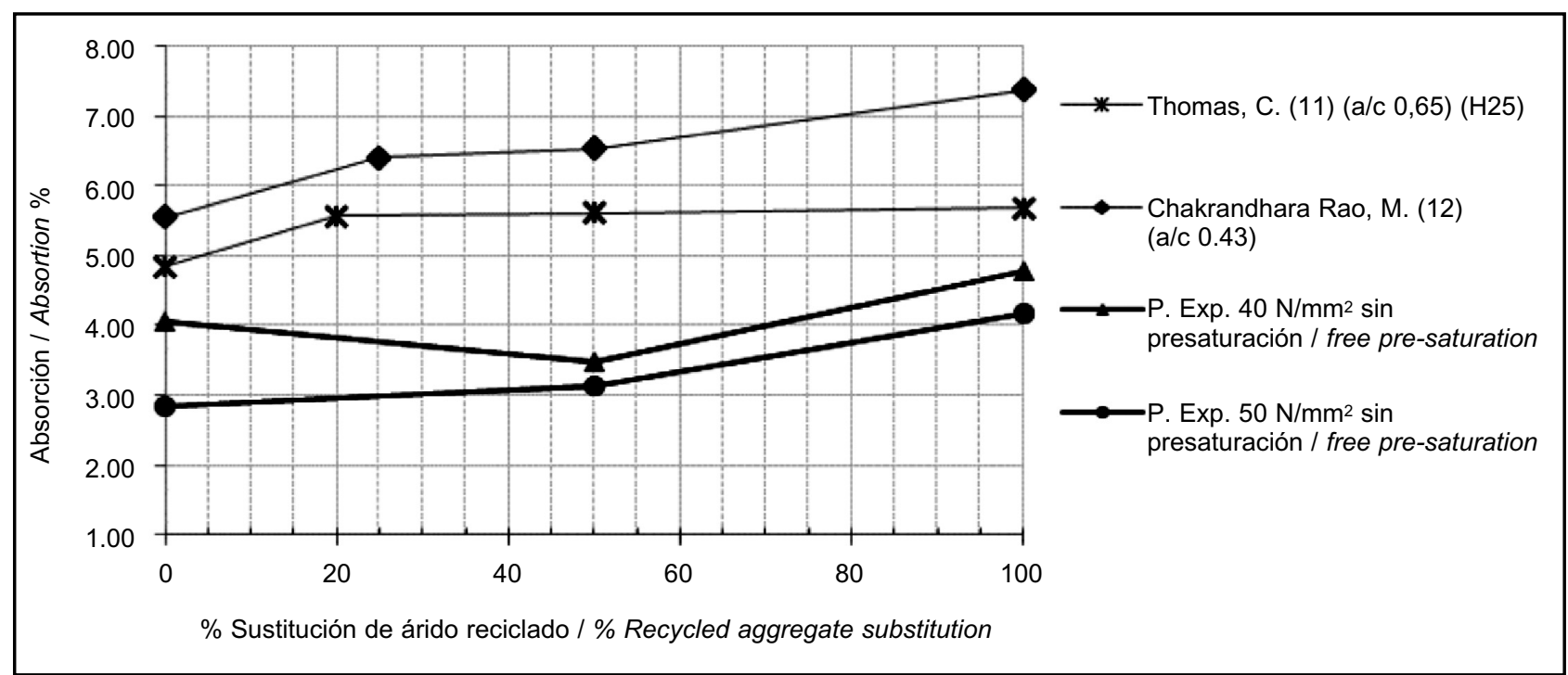

Figura 5. Relación entre \% de absorción y \% de árido reciclado en la mezcla.

Figure 5. Relation between absorption \% and recycled aggregate $\%$ in the batch.

La Figura 5 muestra la relación entre la absorción y el $\%$ de AR sustituido, de los ensayos realizados y su comparativa con otros autores (11-12).

Todas las muestras ensayadas han dado valores de absorción inferiores al 5\%, inferior a los valores obtenidos por otros autores con hormigones reciclados procedentes de residuos de hormigón. El hormigón reciclado presenta una tendencia clara a aumentar la absorción cuando se aumenta el \% de AR.

\subsection{Resistencia a compresión}

La Tabla 5 recoge los valores de los ensayos de resistencia a compresión realizados con probeta cúbica 10×10×10 cm., según la norma UNE-EN 12390-3. La Figura 6 presenta una comparativa de la resistencia a compresión en función del porcentaje de sustitución de $A R$, con referencia a otros autores consultados $(1,4,5,8,13,14)$.
Figure 5 shows the relation between the absorption and the \% of substituted $R A$ in the tests performed and its comparison with other authors (11-12).

All the samples tested have shown absorption values smaller than 5\%, and smaller than values obtained by other authors with recycled concretes coming from concrete waste. Recycled concrete shows a clear tendency to increase absorption when the \% of $R A$ increases.

\subsection{Compressive strength}

Table 5 includes the values of the compressive strength tests performed with $10 \times 10 \times 10 \mathrm{~cm}$ cubic samples, in compliance with UNE-EN 12390-3 standard. Figure 6 presents the compressive strength comparison regarding the percentage of $R A$ substitution, with reference to the authors studied $(1,4,5,8,13,14)$.

Tabla 5 / Table 5

Valores de resistencia a compresión para las distintas dosificaciones. Compressive strength values for the different proportions.

\begin{tabular}{|c|c|c|c|c|c|}
\hline \multirow{10}{*}{ 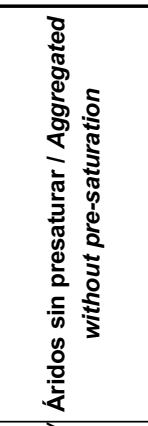 } & \multirow{3}{*}{$\begin{array}{c}\text { Mezcla / mix } \\
\text { 1AR40-0 }\end{array}$} & \multicolumn{4}{|c|}{ Rc 28 días / days $(10 \times 10)\left(F_{\text {conv. }} 0.88\right)$} \\
\hline & & \multicolumn{3}{|c|}{$f_{\mathrm{ck}}\left(\mathrm{N} / \mathrm{mm}^{2}\right)$} & \multirow{2}{*}{$\frac{\mathbf{f}_{\mathrm{ck}, \mathrm{m}}\left(\mathbf{N} / \mathbf{m m}^{2}\right)}{50.40}$} \\
\hline & & 53.9 & 49.7 & 47.6 & \\
\hline & 1AR 40-20 & 55.0 & 54.4 & 54.8 & 54.73 \\
\hline & 1AR 40-50 & 59.9 & 58.9 & 57.0 & 58.60 \\
\hline & 1AR 40-100 & 60.1 & 58.0 & 57.2 & 58.43 \\
\hline & 1AR 50-0 & 62.3 & 60.7 & 58.1 & 60.37 \\
\hline & 1AR 50-20 & 64.3 & 59.4 & 57.9 & 60.53 \\
\hline & 1AR 50-50 & 64.2 & 60.4 & 59.8 & 61.47 \\
\hline & 1AR 50-100 & 65.1 & 60.1 & 57 & 60.73 \\
\hline \multirow{4}{*}{ 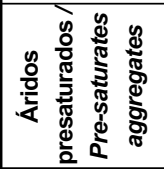 } & 5AR 50-100s & 57.2 & 58.8 & 59.0 & 58.3 \\
\hline & 6AR 50-100s & 45.6 & 44.3 & 45.2 & 45.0 \\
\hline & 7AR 50-100 & 64.1 & 65.6 & 61.5 & 63.7 \\
\hline & 8AR 50-100 & 64.6 & 61.7 & 64.9 & 63.7 \\
\hline
\end{tabular}




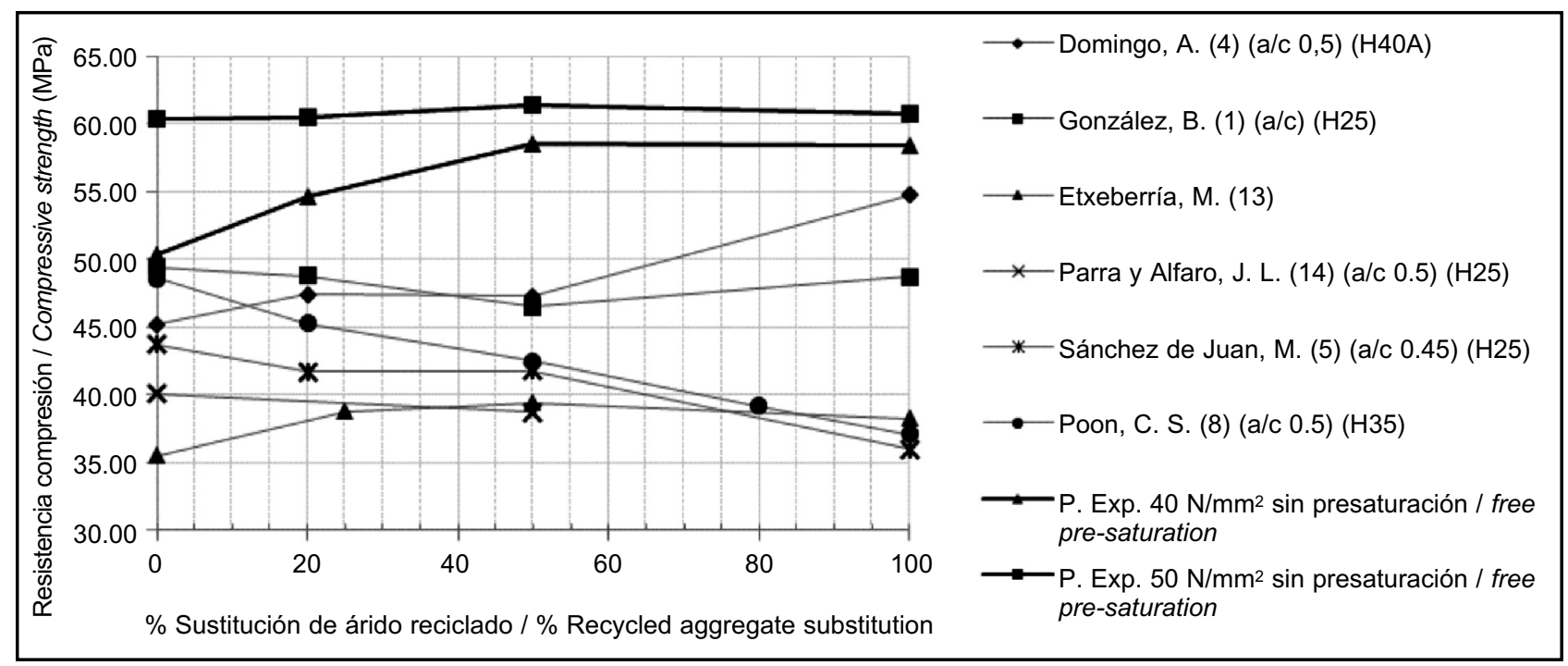

Figura 6. Relación resistencia a compresión y \% árido reciclado en la mezcla.

Figure 6. Relation of compressive strength and \% of recycled aggregate in the batch.

La resistencia del hormigón reciclado a compresión con áridos procedentes de machaqueo de residuos de hormigón estructural sin someterlos a condiciones de presaturación, con roturas de probetas a 28 días curadas en cámara húmeda, es superior a la de un hormigón convencional, con un rango de valores de $8 \%$ a $17 \%$.

Estos incrementos se justifican como consecuencia de la absorción de agua de la pasta de cemento por parte de los áridos reciclados, que modifica la relación $\mathrm{a} / \mathrm{c}$ real de la mezcla, disminuyendo la misma.

Con áridos presaturados los valores de resistencia obtenidos con roturas de probetas a 28 días son inferiores a los del hormigón convencional con valores que oscilan entre $-8 \%$ y $-29 \%$. En esta situación, el AR no absorbe agua de la pasta de cemento manteniéndose la relación inicial.

La resistencia del hormigón reciclado no queda limitada a los valores de la resistencia del hormigón de origen, alcanzado incrementos de resistencia con rotura de probetas a 28 días para los hormigones estudiados del $60 \%$.

\subsection{Resistencia a tracción}

La Figura 7 recoge los resultados de los valores medios de las tres probetas ensayadas para cada una de las tipologías de hormigones ensayados comparándolas con otros autores (5-13).

Los ensayos realizados para la determinación de la resistencia a tracción mediante el Ensayo Brasileño, presentan dispersiones en los valores de resistencia con respecto al hormigón de control de $\pm 15 \%$.
Compressive strength of recycled concrete with aggregate coming from grinded structural concrete waste, without being subject to pre-saturation, and with samples fractured at 28 days and cured in moisture chamber is notably higher than that of a conventional concrete, with values ranging from $8 \%$ to $17 \%$.

These increases are justified as a consequence of the cement paste water absorption from the recycled aggregates, which modify the real $w / c$ ratio of the mixture, diminishing it.

With pre-saturated aggregates, the compressive strength values obtained with samples fractured at 28 days, are smaller than those of a conventional concrete, presenting values oscillating in between $-8 \%$ and $-29 \%$. In this situation, the $R A$ does not absorb water from the cement paste maintaining the initial ratio.

Compressive strength of recycled concrete is not limited to the values of the strength of the original concrete, reaching increases of strength of $60 \%$, with samples fractured at 28 days in the concretes studied.

\subsection{Tensile strength}

Figure 7 shows the results of the average values of the three specimens tested for each of the concrete typologies analyzed, comparing them to those of other authors studied (5-13).

Tests carried out for determining tensile strength using the Brazilian Test show dispersions in the tensile strength values of about de $\pm 15 \%$ in comparison to the reference concrete. 


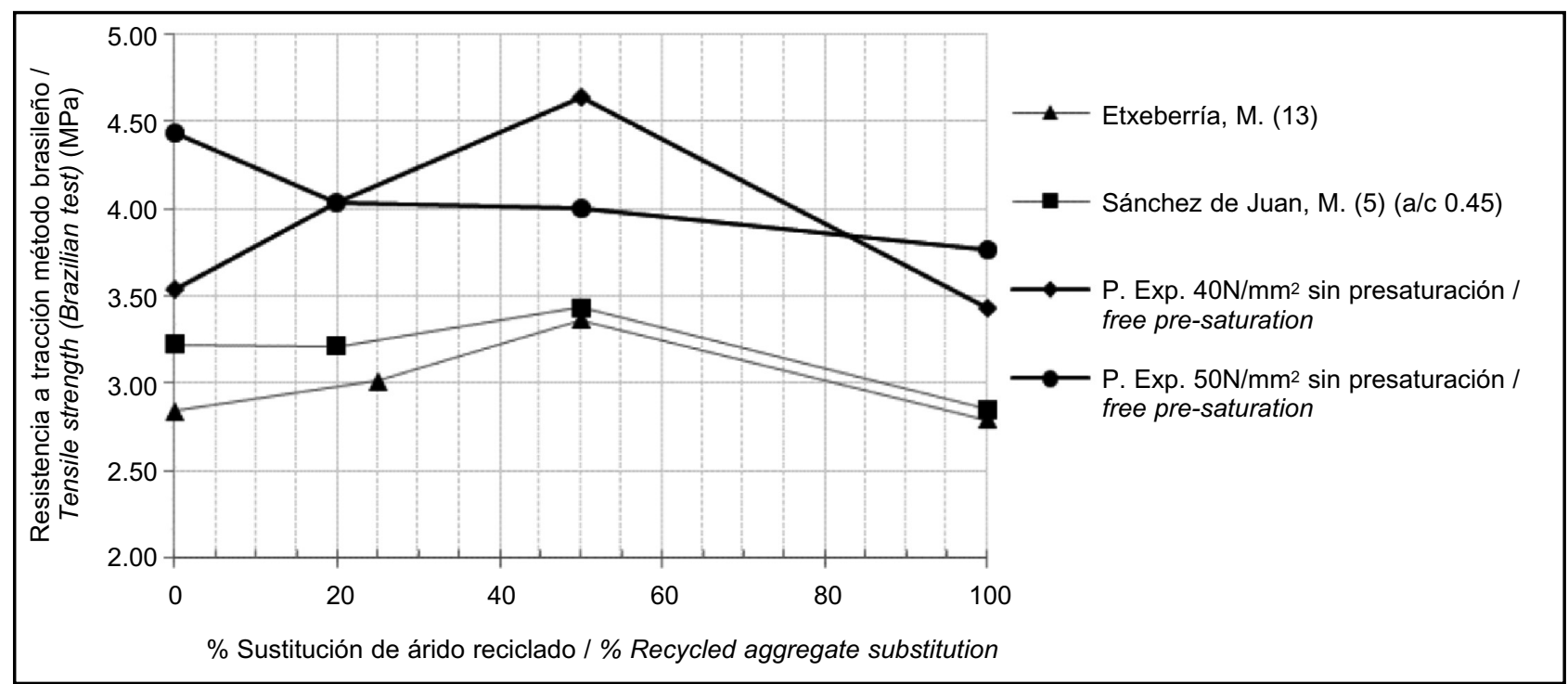

Figura 7. Evolución de la relación entre resistencia a tracción y el \% de árido reciclado de la mezcla. Figure 7. Evolution of the ratio between tensile strength and the \% of recycled aggregate in the batch.

La Tabla 6 muestra los valores de resistencia a tracción según la formulación de EHE-08 con relación a los obtenidos experimentalmente, para las 4 sustituciones, analizando 8 situaciones.

La relación que presenta la EHE-08 entre la resistencia a compresión y tracción indirecta del hormigón reciclado, muestra desviaciones del $12 \%$.
Table 6 shows the tensile strength values in compliance with the EHE-08 formulation relating it to the values experimentally obtained, for the 4 substitutions and analyzing 8 situations.

The relation presented by the EHE-08 between the indirect compressive strength and the tensile strength in recycled concrete shows deviations of $12 \%$.

Tabla 6 / Table 6

Valores de resistencia a tracción según la formulación de EHE-08 con relación a los obtenidos experimentalmente, para las 4 sustituciones, analizando 10 situaciones.

Tensile strength values as formulated by EHE-08 compared with those obtained experimentally for the 4 substitutions, analyzing 10 situations.

\begin{tabular}{|c|c|c|c|c|c|}
\hline Mezcla / Mix & $\begin{array}{l}\operatorname{Rc} 28 d(15 \times 30) \\
\quad\left(\mathrm{N} / \mathrm{mm}^{2}\right)\end{array}$ & $\begin{array}{c}\text { Rti } 28 \mathrm{~d}(15 \times 30) \\
\text { Brasileño }\left(\mathrm{N} / \mathrm{mm}^{2}\right)\end{array}$ & $\begin{array}{l}\text { Desviación estándar / } \\
\text { Standard deviation } \sigma \\
\left(\mathrm{N} / \mathrm{mm}^{2}\right)\end{array}$ & $\begin{array}{c}f_{c t, m}=0.3 f_{c k} 2 / 3 \\
\left(N / m^{2}\right)\end{array}$ & $\begin{array}{c}f_{c t, m}=0.58 f_{c k} 1 / 2 \\
\left(N / m^{2}\right)\end{array}$ \\
\hline 2AR40-0 & 53.95 & 3.53 & 0.61 & - & 4.26 \\
\hline 2AR40-20 & 46.60 & 4.03 & 0.37 & 3.88 & - \\
\hline 2AR40-50 & 51.20 & 4.63 & 0.45 & - & 4.15 \\
\hline 2AR40-100 & 52.55 & 3.43 & 0.26 & - & 4.20 \\
\hline 5AR40-100s & 44.82 & 3.64 & & 3.79 & - \\
\hline 2AR50-0 & 48.40 & 4.43 & 0.45 & 3.98 & - \\
\hline 2AR50-20 & 52.30 & 4.03 & 0.49 & - & 4.19 \\
\hline 2AR50-50 & 59.85 & 4.00 & 0.08 & - & 4.49 \\
\hline 2AR50-100 & 45.10 & 3.77 & 0.40 & 3.80 & - \\
\hline 6AR50-100s & 47.06 & 3.57 & 0.34 & 3.91 & - \\
\hline
\end{tabular}

\section{CONCLUSIONES}

Los resultados de los ensayos realizados del AR han presentado un excelente comportamiento, quedando la absorción y la resistencia a la helada para sustituciones del $100 \%$ con valores muy superiores respecto a los áridos de referencia.

\section{CONCLUSIONS}

The results of the tests performed with RA have shown an excellent performance, especially in absorption and frost strength for $100 \%$ substitutions, with values highly greater to those of the reference aggregates. 
Los ensayos de absorción para el hormigón reciclado han mostrado porcentajes de $2,85 \%$ para el hormigón de referencia y de 4,77\% para las sustituciones de $\operatorname{AR}$ del $100 \%$, quedando la densidad con valores que han oscilado de 2,3 a 2,4 (kg/dm³), evidenciando un buen comportamiento del hormigón reciclado, frente a los valores de absorción y resistencia a la helada del AR.

Los ensayos de resistencia a compresión en la situación de árido reciclado sin someterlo a saturación previa han mostrado valores de resistencia a compresión muy similares en las tres sustituciones estudiadas con respecto al hormigón de comparación, presentando un aumento de resistencia con respecto al hormigón de comparación en los hormigones $\mathrm{H} 40$ con relaciones $\mathrm{a} / \mathrm{c}=0,44$, con un máximo para sustituciones del $50 \%$.

En los hormigones con árido presaturado la resistencia a compresión presento bajas de resistencia del 15-20\% con respecto al hormigón de comparación.

Como conclusión, los resultados de los ensayos realizados indican que hormigones elaborados con áridos reciclados obtenidos por trituración y clasificación de piezas prefabricadas de rechazo en fábrica, pueden presentar una excelente calidad para su uso estructural, con posibles sustituciones de hasta el 100\% para hormigón armado y pretensado, valores superiores a las restricciones de la actual Instrucción EHE-08.

\section{AGRADECIMIENTOS}

Se agradece al grupo de empresas Prainsa, así como al Laboratorio Arco Tecnos que ha hecho posible toda la fase experimental.
Absorption tests for recycled concrete have shown percentages of $2.85 \%$ for the reference concrete and of $4.77 \%$ for $100 \%$ RA substitutions, where the density has varied from 2.3 to $2.4 \mathrm{Kg} / \mathrm{dm}^{3}$, confirming a good performance of $R A$ concrete, as opposed to the absorption and frost values of $R A$.

Compressive strength tests for recycled aggregate not subject to previous saturation, have shown very similar compressive strength values in the three substitutions studied in relation to the reference concrete, showing an increase of strength in $\mathrm{H} 40$ concretes with an $0.40 \mathrm{w} / \mathrm{c}$ ratio, with a maximum for $50 \%$ substitutions.

For concretes with pre-saturated aggregate, the compressive strength shows low strength of $15-20 \%$ in relation to the reference concrete.

A final conclusion can be drawn from the results obtained, which indicate that concrete produced with recycled aggregates obtained from grinding factory discarded prefabricated concrete units, present an excellent quality for structural use, with possible substitutions of up to $100 \%$ for reinforced and prestressed concrete, with values higher than the restrictions of the present regulations of the EHE-08.

\section{ACKNOWLEDGEMENTS}

We thank Prainsa group of companies, as well as techno Arc Lab has made possible the entire experimental phase.

\section{BIBLIOGRAFÍA / BIBLIOGRAPHY}

(1) González-Fonteboa, B., Martínez-Abella, F.: "Hormigones con áridos reciclados: estudio de propiedades de los áridos y de las mezclas", Mater. Construcc., vol. 55, no 279 (2005), pp. 53-66.

(2) Pérez, I., Toledano, M., Gallego, J., Taibo, J.: "Propiedades mecánicas de mezclas bituminosas en caliente fabricadas con áridos reciclados de residuos de construcción y demolición", Mater. Construcc., vol. 57, no 285 (2007), pp. 17-29.

(3) Rolón Aguilar, J. C., Nieves Mendoza, D., Huete Fuertes, R., Blandón González, B., Terán Gilmore, A.: "Caracterización del hormigón elaborado con áridos reciclados producto de la demolición de estructuras de hormigón", Mater. Construcc., vol. 57, n 288 (2007), pp. 5-15.

(4) Domingo, A., Lázaro, C., Gayarre, F., Serrano, M., López-Colina, C.: "Long term deformations by creep and shrinkage in recycled aggregate concrete", Materials and Structures, vol. 47, no 8 (2009), pp. 1147-1160.

(5) Sánchez de Juan, M., Alaejos Gutiérrez, M. P.: "Estudio sobre la utilización de árido reciclado para la fabricación de hormigón estructural". Madrid: Centro de Publicaciones Secretaria General Técnica Ministerio de Fomento (2004).

(6) Gomes, M., de Brito, J.: "Structural concrete with incorporation of coarse recycled concrete and ceramic aggregates: durability performance", Materials and Structures, vol. 42, no 5 (2009), pp. 663-675. http://dx.doi.org/10.1617/s11527-008-9411-9

(7) Limbachiya, M., Leelawat, T, Dhir, R.: "Use of recycled concrete aggregate in high-strength concrete", Materials and Structures, vol. 33 (2000), pp. 574-580. http://dx.doi.org/10.1007/BF02480538 
(8) Poon, C. S., Kou, S., Lam, L.: "Influence of recycled aggregate on slump and bleeding of fresh concrete", Materials and Structures, vol. 40, no 9 (2007), pp. 981-988. http://dx.doi.org/10.1617/s11527-006-9192-y

(9) III Congreso de ACHE de puentes y estructuras. "Las estructuras del siglo XXI, sostenibilidad, innovación y retos del futuro. influencia del árido reciclado en las propiedades del hormigón estructural" (2005), p. 4.

(10) Asociación Científico Técnica del Hormigón Estructural: "Utilización de árido reciclado para la fabricación de hormigón estructural", Madrid, p. 45 (2006).

(11) Thomas, C., Carrascal, I., Setién, J., Polanco, J. A.: "Determinación del límite a fatiga en hormigones reciclados de aplicación estructural", Anales de Mecánica de la Fractura, vol. 1(26) (2009), pp. 283-288.

(12) Chakradhara Rao, M., Bhattacharyya, S., Barai S.: "Influence of field recycled coarse aggregate on properties of concrete", Materials and Structures (en línea). Disponible en: http://www.springerlink.com/content/x88870w520843h47/ (2010, 6 de mayo).

(13) Etxeberría, M., Vázquez, E., Marí, A., Barra, M.: "Influence of amount of recycled coarse aggregates and production process on properties of recycled aggregate concrete", Cem. Concr. Res., vol. 37(5) (2007), pp. 735-742. http://dx.doi.org/10.1016/j.cemconres. 2007.02.002

(14) Parra y Alfaro, J. L., Castilla, J., Palacios, P., Puchol, L.: "Áridos reciclados para hormigón. Prueba industrial", Jornadas nacionales sobre aplicaciones arquitectónicas de materiales, ETS de Arquitectura, Madrid, 2003. 